\title{
Measurement of Oxygen radicals in plasma by laser-induced fluorescence spectroscopy
}

\section{I F 法によるプラズマ中の酸素ラジカルの測定}

\author{
Hiroaki MIYASAKA, Yukihiro KOBAYASHI and Akira TONEGAWA \\ Department of Physics, School of Science, Tokai University, 1117 Kitakaname, \\ Hiratsuka, Kanagawa, 259-12 JAPAN
}

TEL:81-463-58-1211(EXT.3684), FAX:81-463-58-1812

Kazutaka KAWAMURA and Kazuo TAKAYAMA

Institute of Research \& Development, Tokai University, 1117 Kitakaname,

Hiratsuka, Kanagawa, 259-12 JAPAN

TEL:81-463-58-1211(EXT.5300)

( Accepted for publication 8 November 1996 )

In order to investigated the Oxygen radicals in the discharge tube, the $3 \mathrm{p}^{3} \mathrm{P}$ state of $\mathrm{O}$ is populated by twophoton absorption at $226 \mathrm{~nm}$ is detected by the Laser-Induced Fluorescence (LIF) spectroscopy. The O fluorescence emission $(845 \mathrm{~nm})$ increases with increasing the discharge current.

Keywords: Oxygen radicals, Plasma, LIF, Two-photon absorption

\section{I.INTRODUCTION}

酸素ラジカルは、環境問題（オゾン層破壊）、 プラズマプロセス（プラズマエッチングなど） において、重要な役割を果たしている。しかし、 ラジカルの基礎物理量はプローブ法、発光分光 等の通常の方法では測定が困難であり、未解決 の問題が多い。そこで、この実験の目的は、酸 素プラズマ中の酸素ラジカルを及びLIF法（レー ザー誘起蛍光法）によって測定し、プラズマパ ラメータによるラジカル量の変化を測定する事 を目的とする。

\section{II .EXPERIMENTAL}

Figure 1 に 2 光子励起によるLIF法の原理を示 す。 ${ }^{2,3}$ 酸素プラズマは直接励起によるLIF法では 吸収のために测定が困難であり、そのために 2 光子励起法を用いる。 $226 \mathrm{~nm}$ のレーザーのより 2 光子励起された原子の一部は蛍光を発し、一 部はさらに励起光を吸収してイオン化する。
LIF法では、この蛍光 $845 \mathrm{~nm}$ を測定する。2 光子 励起の問題点としては、直接励起に比心゙て、断 面積が小さいので高いパワー密度のレーザーが 必要となる。

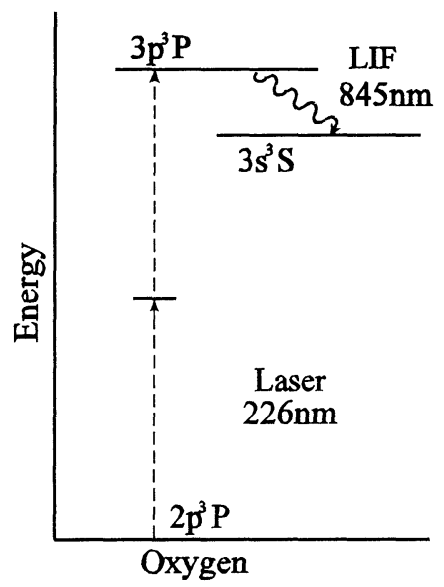

FIG. 1. Principle of the LIF methode 


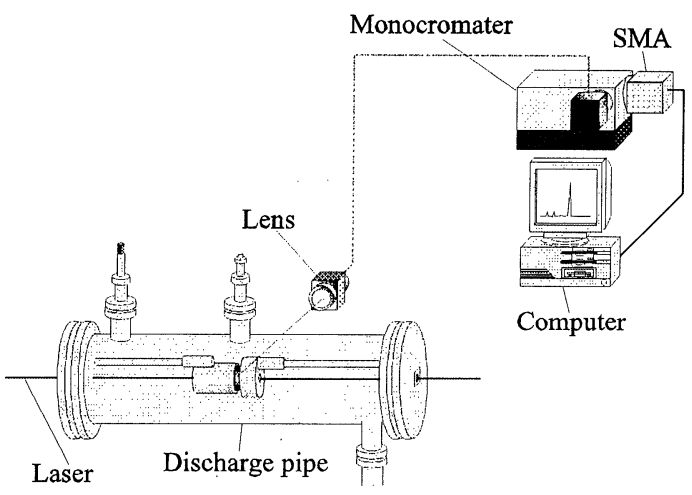

FIG. 2. The measurement system.

実験装置及び測定システムの概念図をFig. 2に 示す。実験方法は、円筒形電極の放電管内酸素 中でグロー放電を発生させ、226nmのレーザー を入射し、2 光子励起によるLIF蛍光 $845 \mathrm{~nm}$ を $32 \mathrm{~cm}$ Czerny-Turner型モノクロメータ及び、マルチ チャンネルアナライザー(SMA)で分光测定した。

励起用レーザーは、YAG励起の色素レーザー を利用して、537.9nmのレーザーを発生、非線形 結晶により倍波286.95nmを発生させ、YAGレー ザーの基本波1064nmとミキシングし、226nmを 発振させた。

実験では放電電流 $\mathrm{I}_{\mathrm{d}}$ を20mAから100mA、ガス 圧 $\mathrm{P}_{\mathrm{s}}$ を40から $267 \mathrm{~Pa}$ まで変化させ、LIF蛍光 845nmの変化を調べた。

\section{III.RESULT}

Figure 3は放電電流 $I_{\mathrm{d}}$ 変化させたときのLIF蛍 光を示している。放電管内の酸素ガス圧は 67Paである。蛍光強度は放電電流の変化ととも に増加した。

Figure 4は放電管内の酸素ガス圧力P $\mathrm{s}$ を変化さ せたときのLIF蛍光の変化を示している。放電電 流 $\mathrm{I}_{\mathrm{d}}=100 \mathrm{~mA}$ である。ガス圧が67Paのときに蛍光 強度がピークとなった。

\section{IV.CONCLUSION}

円筒形電極を用いた放電管内において、 2 光 子励起によるLIF法により酸素ラジカルを検出した。 LIF蛍光、つまり酸素ラジカルの生成量は放電電流 に比例して増えることがわかる。また、放電管 内の酸素ガス圧力変化させると、67Paのときに もっとも酸素ラジカルが生成されることがわか る。

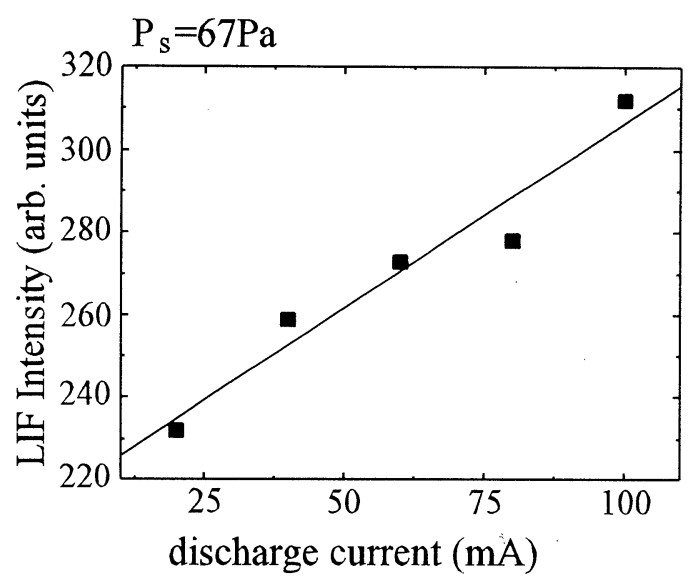

FIG. 3. LIF Intensity are plotted against discharge current.

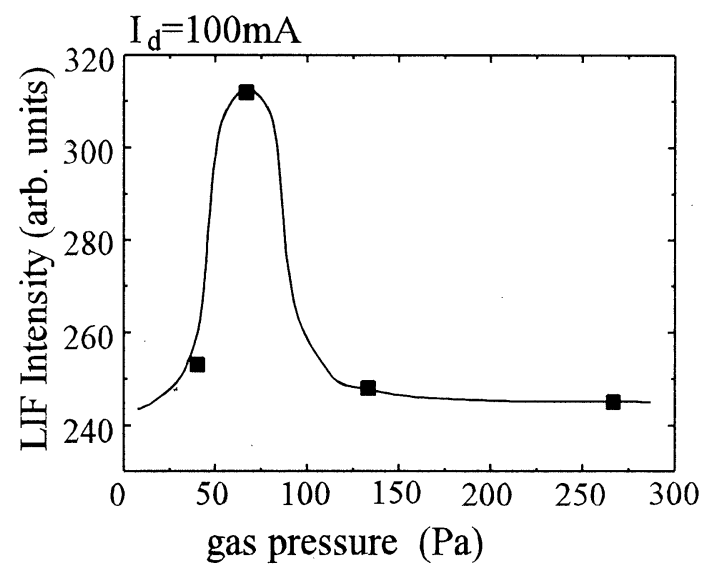

FIG. 4. LIF Intensity are plotted against $\mathrm{O}_{2}$ gas pressure

\section{REFERENCES}

${ }^{1}$ Kunihide Tachibana : Bunkoukenkyu 37, 142 (1998)

${ }^{2}$ William K. Beschel, Bryce E. Perry, and David R.

Crosley : Appl. Opt. 21, 1419 (1982)

${ }^{3}$ L.F.Dimauro,R.A.Gottscho, and T.A.Miller : J. Appl. Phys. 56, 2007 (1984)

'96 SAS Intelligent Symposium 